\title{
Book Review: \\ Doctorates Downunder: Keys to Successful Doctoral Study in Australia and New Zealand
}

\author{
Victoria Wise \\ School of Accounting and Corporate Governance, \\ University of Tasmania, Hobart, Tasmania, Australia
}

\author{
Victoria.wise@utas.edu.au
}

\begin{abstract}
C. Denholm and Evans' (2006) Doctorates Downunder: Keys to successful doctoral study in Australia and New Zealand is a collection of essays designed to guide prospective and current doctoral candidates as well as first time supervisors through the maze of doctoral study. The aim of the book is to provide a useful and generic source reference showcasing examples of helpful advice that experienced supervisors can give to doctoral candidates. Such advice is provided in order to make doctoral candidates' journey more enlightened and, ultimately, successful. Specifically designed for the Australian and New Zealand audience, the Denholm and Evans book contains clear and practical advice that would benefit doctoral students across all disciplines and in other countries as well.
\end{abstract}

As a doctoral supervisor I considered C. Denholm and Evans' (2006) book essential reading simply to ensure I kept up-to-date with developments and the literature. Often an academic tome acts as a highly effective soporific. I was not prepared for the opposite effect and found myself racing through roughly $70 \%$ of the book, before I was even tempted to put out the light and snatch an hour or two of sleep!

C. Denholm and Evans' (2006) book takes the reader on a well-structured journey through the bewildering task of embarking on and successfully completing a Ph.D. It makes compelling reading for both Ph.D. candidates and their supervisors. The book is structured as nine separate sections containing 28 short chapters. Each section complements the information and advice provided in earlier sections, commencing with the beginning of the 'journey' and culminating in the 'end game' or life after the Ph.D. The author(s) of each chapter has acquired an impressive range and depth of doctoral supervision. Each conveys their advice with a real sense of the challenges and rewards that doctoral candidates are likely to experience. I was able to make a personal connection with the content in most chapters and found myself rueful that I did not have the opportunity to read such a book before or during my own Ph.D. candidature. It would have clarified

Material published as part of this publication, either on-line or in print, is copyrighted by the Informing Science Institute. Permission to make digital or paper copy of part or all of these works for personal or classroom use is granted without fee provided that the copies are not made or distributed for profit or commercial advantage AND that copies 1) bear this notice in full and 2) give the full citation on the first page. It is permissible to abstract these works so long as credit is given. To copy in all other cases or to republish or to post on a server or to redistribute to lists requires specific permission and payment of a fee. Contact Publisher@InformingScience.org to request redistribution permission. many matters for me and eased my concerns on a number of issues.

C. Denholm and Evans' (2006) book provides coverage of numerous common issues facing doctoral candidates. These common issues include: beginning candidature and selection of a supervisor; countering isolation by working with peers and librarians as well as other support structures; making university and industry links; acquiring generic 
skills including becoming a critical and an ethical researcher; managing personal obstacles and maintaining a healthy work-life balance; applying effective and timely strategies for communicating research; writing the dissertation; preparing the dissertation (and the candidate) for examination; and finally, knowing what to expect after completion of the Ph.D. This arrangement provides a coherent and logical sequence to the essay collection, while also permitting the reader to move directly to chapters dealing with particular issues without the need to read earlier chapters. Chapters are formatted for easy reading with attention to headings, introductions, figures, numbered, and bullet points. Each chapter concludes with a set of reflective questions prompting the reader to consider the implications of the subject matter for their own research, discipline, or circumstances.

As I read through C. Denholm and Evans' (2006) book, I found myself book-marking pages for future reference. In particular I found the following chapters to contain useful and poignant material. In Chapter 7 'The librarian-the candidate's forgotten friend' Macauley (2006) provided reference to the Web of Knowledge as a particularly useful "bibliographic resource which enables the researcher to navigate forward, backward and through the literature, searching all disciplines and time spans to uncover information" relevant to their own research (pp.54-55). Awareness of library and bibliographic resources as well as the ability to locate and manipulate those resources are important skills that may take a doctoral candidate some time to acquire. Macauley pointed out that librarians can provide an invaluable service in assisting in the acquisition of these skills.

In Chapter 12 'On being a critical researcher' Barnacle (2006) encouraged self-reflexive thinking about the forms that criticality takes in personal research practice. Barnacle also provided a useful 11-point reasoning strategy (from Browne \& Keeley, 2001) for establishing and evaluating an argument, together with exercises demonstrating the skills as well as the capabilities that need to be employed when evaluating and establishing arguments. An often vexatious issue is the attribution of authorship of a publication. J. Denholm (2006) in Chapter 13 'On being an ethical researcher' suggested some helpful guidelines including that "only those who participate throughout the design, implementation and writing-up stages should be co-authors" (p.109). He also pointed out that in many fields such guidelines might be contrary to established protocols and that candidates might be under pressure (subtle or otherwise) to include influential colleagues to be named as authors.

C. Denholm (2006) and Evans (2006) covered a number of important personal considerations in Chapter 15, 'Some personal obstacles to completion', and Chapter 17, 'Part-time candidaturebalancing candidature, work and personal life'. In these chapters the reader is made aware of the importance of leading the candidate through the process of self-counselling and of raising awareness of the self-discipline needed to sustain a programme of intense study across a number of years. Issues such as fractured relationships, exhaustion, and work-life balance are discussed in these two chapters. Moreover, much useful advice pertaining to family matters and commitment to $\mathrm{Ph} . \mathrm{D}$. studies is provided in these two chapters.

In my view, a more explicit consideration of the symbiotic relationship between supervisor and student as well as the power relationships would have added a useful dimension to C. Denholm and Evans' (2006) book. On the whole, their book offers an excellent and accessible collection of useful guidance for doctoral candidates who are either just embarking upon, or at any stage of their Ph.D. studies. I have already commended specific chapters of this book to some of my own doctoral candidates, and purchased the book for our in-house resource collection. 


\section{References}

Barnacle, R. (2006). On being a critical researcher. In C. Denholm \& T. Evans (Eds.), Doctorates downunder: Keys to successful doctoral study in Australia and New Zealand (Ch 12, pp. 95-103). Camberwell, Australia: ACER Press.

Browne, M., \& Keeley, S. (2001). Asking the right questions: A guide to critical thinking. New Jersey: Prentice-Hall.

Denholm, C. (2006). Some personal obstacles to completion. In C. Denholm \& T. Evans (Eds.), Doctorates downunder: Keys to successful doctoral study in Australia and New Zealand (Ch 15, pp. 122-128). Camberwell, Australia: ACER Press.

Denholm. C., \& Evans, T. (Eds.). (2006). Doctorates downunder: Keys to successful doctoral study in Australia and New Zealand. Camberwell, Australia: ACER Press. ISBN: 0864314299 (paperback). 227 pages. A $\$ 34.95$.

Denholm. J. (2006). On being an ethical researcher. In C. Denholm \& T. Evans (Eds.), Doctorates downunder: Keys to successful doctoral study in Australia and New Zealand (Ch 13, pp. 104-111). Camberwell, Australia: ACER Press.

Evans, T. (2006). Part-time candidature-balancing candidature, work and personal life. In C.Denholm \& T. Evans (Eds.), Doctorates downunder: Keys to successful doctoral study in Australia and New Zealand (Ch 17, pp, 136-142). Camberwell, Australia: ACER Press.

Macauley, P. (2006). The librarian-the candidate's forgotten friend. In C.Denholm \& T. Evans (Eds.), Doctorates downunder: Keys to successful doctoral study in Australia and New Zealand (Ch 7, pp. 50-58). Camberwell, Australia: ACER Press.

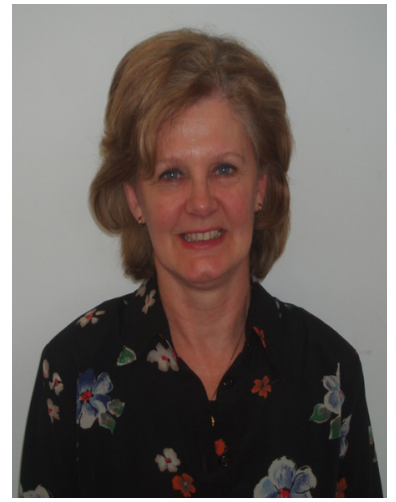

\section{Biography}

Professor Victoria Wise is the Head of the School of Accounting and Corporate Governance at the University of Tasmania, Australia. During her 20 years as an academic she has taught financial accounting and auditing to undergraduate and postgraduate students. Victoria has contributed to over 130 publications including books, chapters, refereed and professional journal articles and conference proceedings. Her journal articles focus on international financial reporting standards, public sector accounting and government policy, and consolidated and small business reporting and regulation. Her current research interests include the regulatory burden on business, and corporate governance and accountability issues.

Victoria has a particular interest in small business, local government, and financial services regulation. She encourages her postgraduate students to focus on issues in these areas. Currently she is supervising $\mathrm{Ph}$.D. candidates who are addressing issues faced by accounting and tax practitioners in the context of a complex tax regime; explicit fraud awareness as a facilitator of judgment efficacy; the effect of change in ownership structure of reformed state-owned enterprises on corporate governance in China; and the role of education in a choice of fund pension system. Victoria is an active editorial advisor and reviewer. Currently she has the following editorial appointments: editorial board member of the New Zealand Journal of Applied Business Research; associate editor for Global Business and Economics Review (www.inderscience.com/gber); and editorial reviewer for the International Journal of Doctoral Studies. She also reviews academic manuscripts and is active in the examination of research theses. 